\title{
PELATIHAN PEMBUATAN MEDIA UNTUK PEMBELAJARAN JARAK JAUH
}

\author{
${ }^{1)}$ Nizaruddin, ${ }^{2)}$ Muhtarom, ${ }^{3)}$ Aryan Eka Prastya Nugraha \\ Universitas PGRI Semarang, Jalan Sidodadi Timur No. 24 Semarang \\ 1email: nizaruddin@upgris.ac.id.
}

\begin{abstract}
ABSTRAK
Kemampuan guru dalam membuat media untuk pembelajaran jarak jauh harus ditingkatkan. Kegiatan pengabdian ini bertujuan untuk memberikan pelatihan dan pendampingan kepada guru dalam membuat video pembelajaran dengan berbagai software. Kegiatan dilaksanakan secara daring menggunakan Zoom Meting selama empat hari kegiatan. Pelatihan dilakukan menggunakan pendekatan andragogi, dimana pelatihan lebih menekankan pada praktek daripada teori. Hasil kegiatan pelatihan menunjukkan bahwa peserta memiliki pemahaman yang meningkatkan terkait pemanfaatan software untuk membuat video pembelajaran. Pemahaman ini ditunjukkan dari peningkatan dari nilai pretest dan postest. Sedangkan kemampuan dalam pembuatan media ditunjukkan dari produk media pembelajaran yang telah dibuat oleh guru.
\end{abstract}

Kata Kunci: Pelatihan, Media, dan Pembelajaran Jarak Jauh. 


\section{PENDAHULUAN}

Sebelum pandemi covid-19 seperti saat ini, video pembelajaran biasanya digunakan hanya untuk menunjang kegiatan tatap muka. Tetapi, pada masa pandemi seperti ini merupakan sebuah tantangan bagi seorang guru dalam memilih media yang tepat yaitu video pembelajaran. Media pembelajaran sangat dibutuhkan karena dapat meningkatkan efisiensi pembelajaran, menstimulasi siswa untuk belajar, dan meningkatkan motivasi belajar siswa (Marlena, Dwijayanti, \& Edwar, 2018; Yang, Liu, Guo, \& Wang, 2012). Media pembelajaran akan optimal apabila siswa termotivasi belajar dan mengikuti proses pembelajaran dengan baik (Barra, Herrera, Cano, \& Vives, 2014). Media pembelajaran yang dikemas dengan baik akan sangat efisien untuk mendukung tercapainya tujuan pembelajaran (Hanum, 2013).

Video pembelajaran merupakan media yang menyajikan informasi yang terdiri dari teks, suara, animasi (Marjuni \& Harun, 2019; Nopriyanti \& Sudira, 2015; Rusmiyati, Nurkamto, \& Haryanto, 2014). Penggunaan media ini untuk pembelajaran jarak jauh merupakan sebuah inovasi yang dapat membantu siswa dalam pemahaman materi, presentasi, dan memotivasi siswa untuk belajar (Herbst \& Chazan, 2015; Kumar, Muniandy, \& Yahaya, 2019). Materi ajar harus dibuat secara terstruktur dalam media sehingga siswa memiliki pemahaman, membantu siswa belajar karena pembelajaran dapat diulang dengan memutar kembali video pembelajaran (Hendriyani et al. 2018). Media pembelajaran dengan konsep pembelajaran jarak jauh (PJJ) harus dapat dilakukan dengan cara daring/tidak tatap muka. Media pembelajaran untuk pembelajaran jarak jauh (PJJ) harus mampu memfasilitasi siswa untuk belajar secara mandiri, mampu memotivasi, memahamkan materi ajar ke siswa (Kusuma, Jaka Wijaya; Jefri, Ulfi; Surnani, Endang; Pratiwi, Ika; Kurniawan, 2020). Kegiatan belajar mengajar dengan menggunakan video pembelajaran akan fleksibel karena siswa dapat mengakses dan melakukan pembelajaran kapan-pun dan dimana-pun berada. Kegiatan pembelajaran menjadi sangat fleksibel atau dapat dilakukan kapan pun dan dimanapun, karena disesuaikan dengan ketersedian waktu peserta didik dengan pendidiknya (Dai \& Fan, 2012). Media ini sangat cocok digunakan untuk kegiatan pembelajaran di tengah pandemi saat ini. Namun demikian, kemampuan guru dalam memanfaatkan media pembelajaran berbasis TIK seperti membuat media video masih rendah ditambah. 
Berdasar latar belakang tersebut penting sekali dilakukan pelatihan dan pendampingan bagi guru dalam pembuatan media untuk pembelajaran jarak jauh. Pelatihan ini dapat meningkatkan kesadaran pentingnya penggunaan media pembelajaran secara daring untuk mempersiapkan anak didik untuk menghadapi era digital.

\section{METODE PELAKSANAAN}

Pelatihan pembuatan media pembelajaran jarak jauh ini diikuti sebanyak 36 guru yang telah mendaftar sebagai peserta pelatihan. Pelatihan dilaksanakan secara daring menggunakan Zoom Meeting selama 4 hari. Pelatihan diawali dengan pentingnya media video untuk pembelajaran jarak jauh selama pandemi Covid-19, kemudian dilanjutkan materi pembuatan video pembelajaran menggunakan powerpoint, pembuatan video pembelajaran menggunakan Filmora, pembuatan video pembelajaran menggunakan Camtasia, pembuatan video pembelajaran menggunakan Kinemaster, dan Pemanfaatan WhatApps Group (WAG) sebagai sarana media konferensi untuk pembelajaran jarak jauh.

Guru yang telah dilatih secara teori dalam pemanfaatan beberapa software untuk membuat media pembelajaran jarak jauh selanjutnya membuat video pembelajaran dengan pendampingan dari fasilitator pelatihan Cendekia FPMIPATI Universitas PGRI Semarang. Langkah-langkah pelatihan dan pendampingan untuk mengatasi permasalahan mitra adalah:

\section{Perencanaan}

Melalukan analisis kebutuhan yang diperlukan guru dalam membuat video pembelajaran, fasilitator dan tim pengabdian menyusun perencanaan pelaksanaan pelatihan meliputi tanggal pelaksanaan pelatihan, jadwal pelatihan selama 4 hari, setting pelatihan, dan penyusunan materi pelatihan.

2. Pelaksanaan

Pelatihan dilaksanakan selama 4 hari dan dipandu oleh fasilitator dari PPUPIK Cendekia FPMIPATI Universitas PGRI Semarang. Walaupun pelatihan dilaksanakan secara daring, tetapi konsep pendekatan andragogi tetap dipertahakan selama kegiatan pelatihan. Pemahaman materi dan praktek pembuatan media menjadi prioritas dalam pelatihan ini. Materi pelatihan disajikan 
dengan lebih banyak praktek dari teori yang disajikan pada Tabel 1.

Tabel 1

Materi Pelatihan Media Pembelajaran Jarak Jauh

\begin{tabular}{|c|c|c|c|}
\hline Hari ke- & Materi & Metode & Keterangan \\
\hline 1 & $\begin{array}{l}\text { - Pengembangan Video Pembelajaran } \\
\text { dengan Powerpoint } 2019 \\
\text { - Pembuatan Media Pembelajaran dengan } \\
\text { ISpring } \\
\text { - Pembuatan Aplikasi Android (APK) dan } \\
\text { Instalasi Aplikasi pada HP Android }\end{array}$ & \multirow{3}{*}{$\begin{array}{l}\text { demonstrasi } \\
\text { tanya jawab, } \\
\text { dan praktek }\end{array}$} & \multirow{3}{*}{$\begin{array}{l}30 \% \text { teori } \\
70 \% \\
\text { praktek }\end{array}$} \\
\hline 2 & $\begin{array}{l}\text { Pengembangan Video Pembelajaran } \\
\text { dengan Filmora } \\
\text { - Pengembangan Video Pembelajaran } \\
\text { dengan Kinemaster }\end{array}$ & & \\
\hline 3 & $\begin{array}{l}\text { Pengembangan Video Pembelajaran } \\
\text { dengan Camtasia Studio } \\
\text { - WhatsApp untuk Kuis \& Video } \\
\text { Conference Pembelajaran Jarak Jauh }\end{array}$ & & \\
\hline 4 & $\begin{array}{l}\text { - } \begin{array}{l}\text { Praktek Pembuatan Video Pembelajaran } \\
\text { dengan Powerpoint }\end{array} \\
\text { - Praktek Pembuatan Video Pembelajaran } \\
\text { dengan Filmora } \\
\text { - Praktek Pembuatan Video Pembelajaran } \\
\text { dengan Kinemaster } \\
\text { - Praktek Pembuatan Video Pembelajaran } \\
\text { dengan Camtasia Studio }\end{array}$ & $\begin{array}{l}\text { praktek \& } \\
\text { pendampingan }\end{array}$ & $\begin{array}{l}100 \% \\
\text { praktek }\end{array}$ \\
\hline
\end{tabular}

3. Evaluasi

Evaluasi pelatihan dilakukan terhadap peserta oleh tim PPUPIK Cendekia FPMIPATI Universitas PGRI Semarang. Soal pretest dan postest diberikan kepada peserta pelatiha untuk mengetahui kemajuan pemahaman dan pengetahuan peserta terhadap materi pelatihan. Sedangkan hasil kerja praktek berupa media video pembelajaran digunakan sebagai bahan penilaian bahwa peserta telah mampu membuat video untuk media pembelajaran jarak jauh.

\section{HASIL DAN PEMBAHASAN}

Kegiatan pengabdian kepada masyarakat ini dilaksanakan secara daring selama 4 hari dengan pola 
32 Jam Pelajaran yang diikuti oleh 36 peserta. Kegiatan ini secara umum terdiri dari 3 sesi teori dan pendampingan yaitu penyampaian materi tentang pengembangan video pembelajaran dengan Powerpoint 2019. Pada tahap pertama dipaparkan materi tentang tahapan dalam pembuatan video pembelajaran menggunakan Powerpoint 2019 serta mengintegrasikannya menjadi aplikasi android (APK) yang dapat diinstalasi pada HP Android. Materi ini diberikan karena powerpoint merupakan media yang sering digunakan oleh guru. Penyajian materi ini disajikan pada Gambar 1.

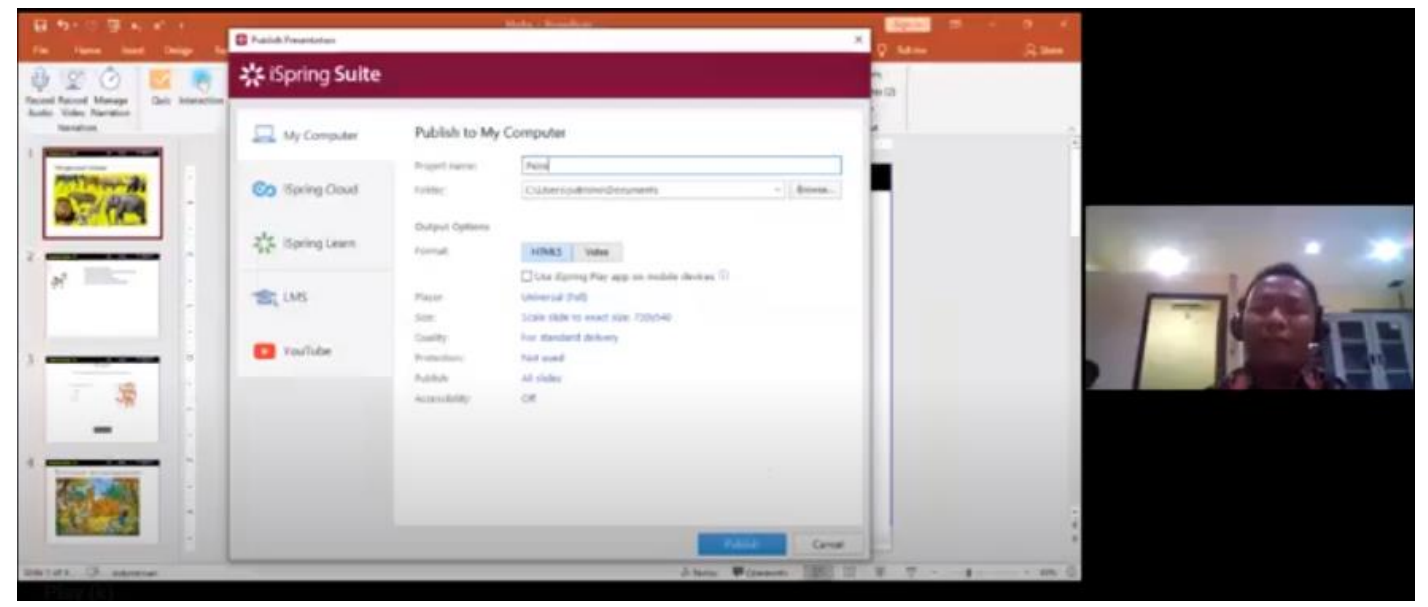

Gambar 1. Penyajian Materi Pembuatan Video dengan Powerpoint 2019

Selanjutnya pada tahap kedua, kegiatan ini diisi oleh materi tentang pembuatan video pembelajaran dengan Filmora dan Kinemaster. Materi disampaikan dengan model pemaparan dan tahapan memandu oleh fasilitator sehingga peserta benar-benar memahami, mampu, dan dapat membuat video pembelajaran yang menarik menggunakan filmora dan kinemaster. Penyajian materi ini disajikan pada Gambar 2. 


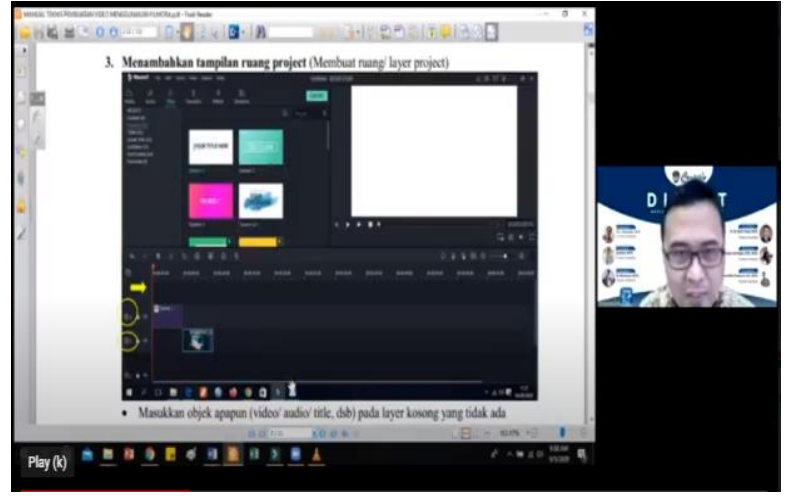

(a) Pembuatan Video dengan Filmora

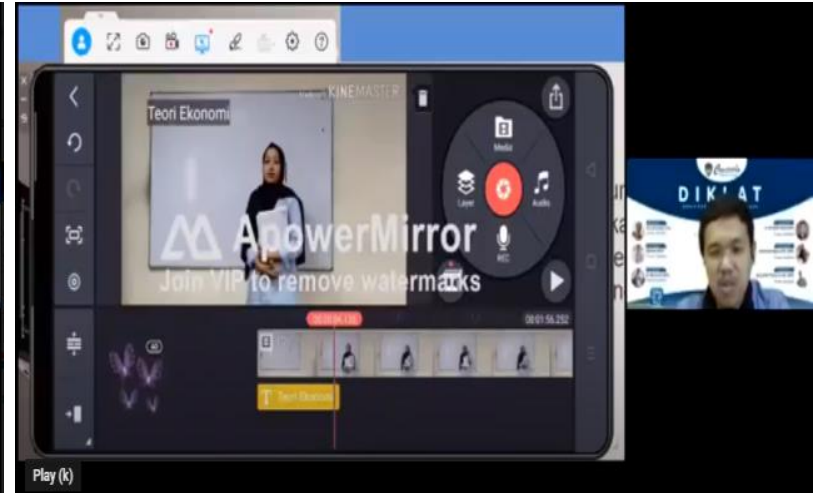

(b) Pembuatan Video dengan Kinemaster

Gambar 2. Penyajian Materi Pembuatan Video dengan Filmora dan Kinemaster

Pada tahap ketiga kegiatan ini diisi oleh materi tentang pembuatan video pembelajaran dengan Camtasia Studio dan WhatsApp untuk kuis \& video conference pembelajaran jarak jauh. Materi juga disampaikan dengan model pemaparan dan tahapan memandu oleh fasilitator sehingga peserta benar-benar memahami, mampu, dan dapat membuat video pembelajaran yang menarik menggunakan Camtasia Studio. Penyajian materi ini disajikan pada Gambar 3.

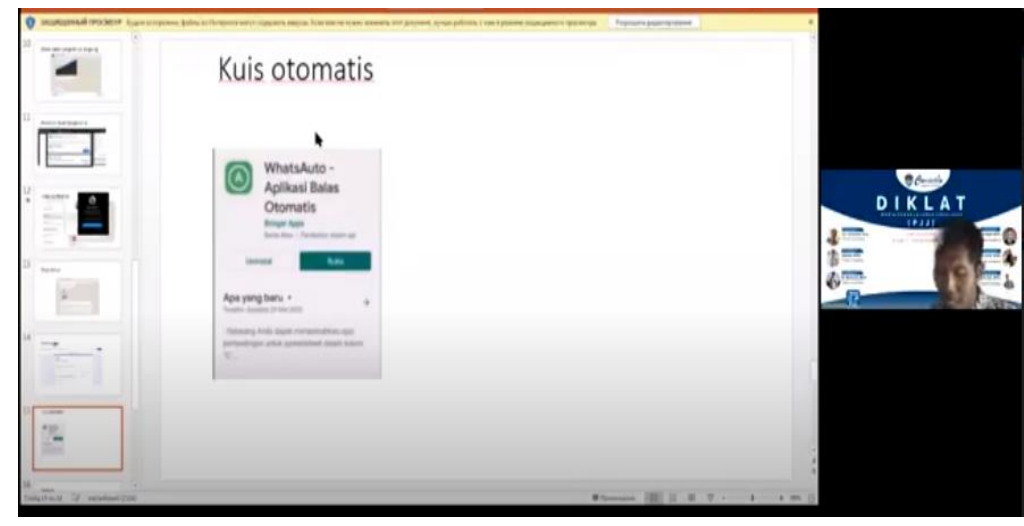

Gambar 3. Penyajian Materi Pemanfaatan WAG

Sesi terakhir adalah pendampingan oleh fasilitator kepada peserta dalam membuat video sebagai media pembelajaran jarak jauh. Pada tahap ini fasilitator memandu setiap peserta untuk dapat praktek secara langsung dalam pembuatan video pembelajaran. Peserta sangat antusias dan dapat mengikuti masukan perbaikan media yang diberikan fasilitator selama pelatihan. Hal ini ditunjukkan dari seluruh peserta pelatihan telah berhasil membuat video pembelajaran. Gambar 4 
menunjukkan contoh produk video dari peserta selama kegiatan pendampingan pembuatan video pembelajaran jarak jauh. Hasil ini sejalan dengan peningkatan pemahaman dari peserta yang ditunjukkan dari skor pretest dan postest yang diberikan oleh tim pengabdi Cendekia FPMIPATI Universitas PGRI Semarang (Gambar 5).
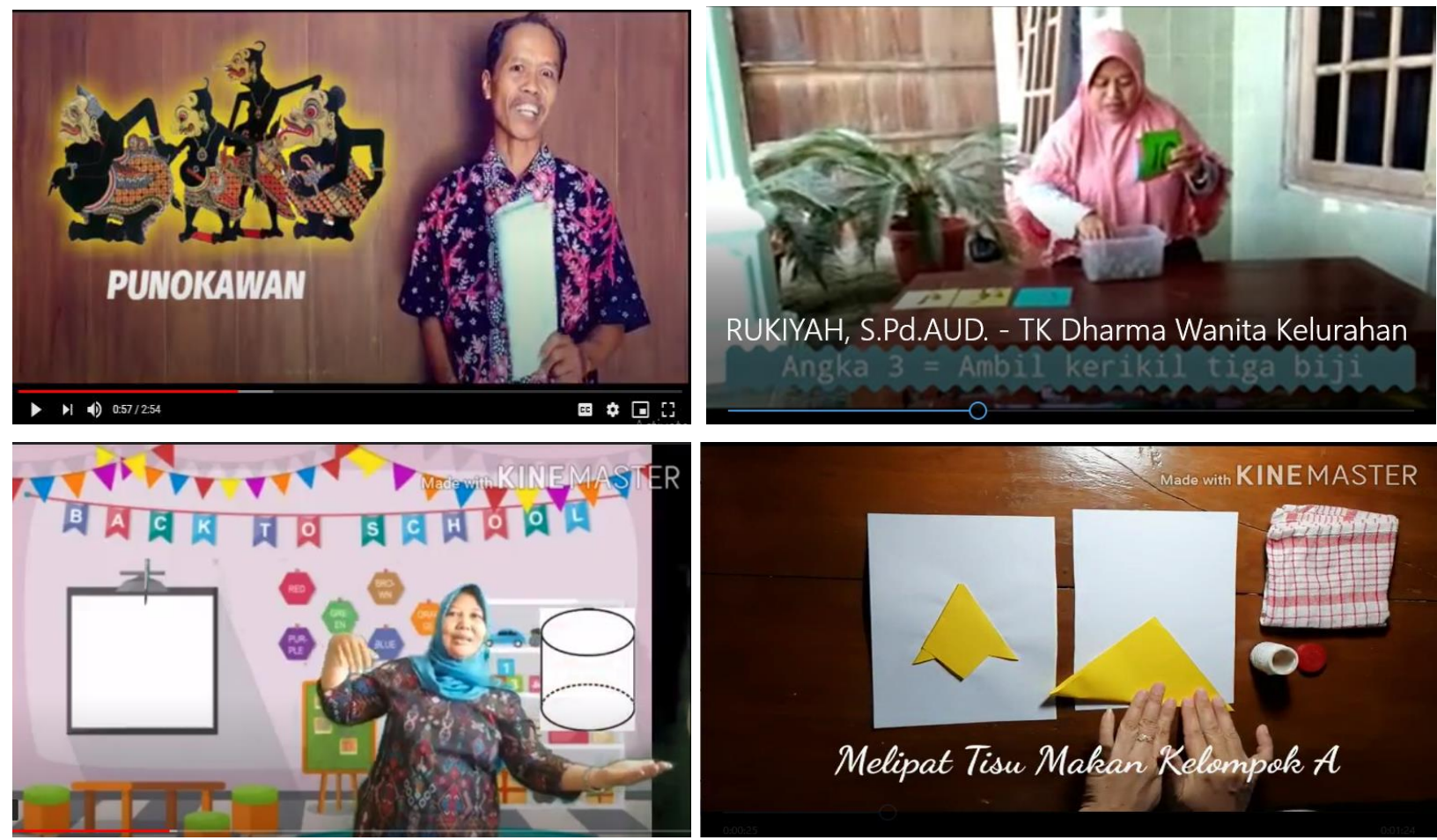

Gambar 4 Hasil Kerja Peserta Pelatihan Media PJJ

Hasil Pretest dan Postest

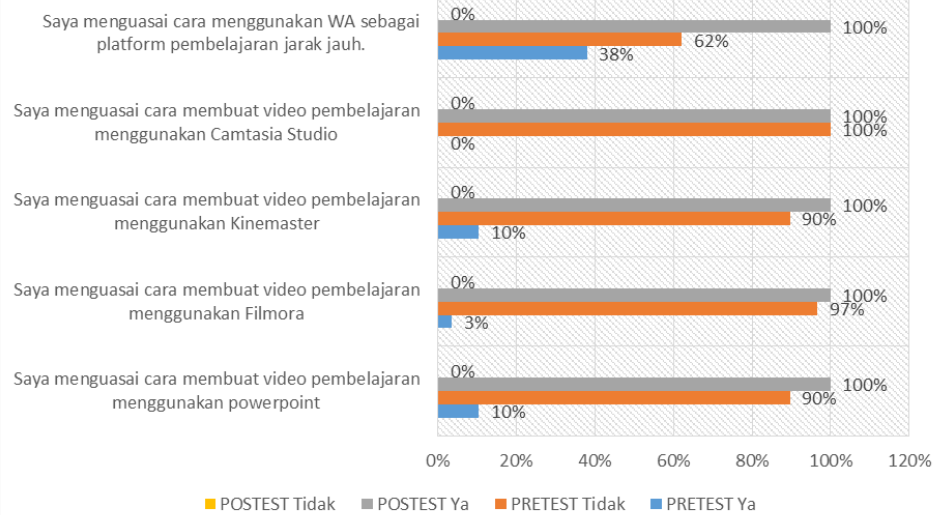

Gambar 5 Rerata skor Pretest dan Postest 
Hasil pelatihan ini menunjukkan bahwa guru mampu untuk membuat video yang dapat memberikan pengalaman kepada siswa serta diharapkan dapat meningkatkan prestasi belajar siswa selama pandemic Covid-19. Ini sejalan dengan pendapat Marlena, Dwijayanti, \& Edwar (2018) dan Yang, Liu, Guo, \& Wang (2012) yang menjelaskan bahwa multimedia mampu memberi pengalaman untuk siswa, meningkatkan pembelajaran, memberikan informasi materi secara luas sehingga dapat meningkatkan hasil belajar. Peserta pelatihan telah menunjukkan bahwa guru harus dapat meningkatkan inovasi pembelajaran dan mempermudah siswa dalam memahami materi ajar. Ini sejalan dengan pendapat Barra, Herrera, Cano, \& Vives (2014) yang menjelaskan bahwa untuk membuat siswa termotivasi belajar dapat digunakan media video yang menarik siswa.

\section{PENUTUP}

Kegiatan pengabdian kepada masyarakat pembuatan media pembelajaran jarak jauh telah dapat meningkatkan pemahaman guru dalam pembuatan video menggunakan berbagai macam software. Ini ditunjukkan dari pemahaman peserta yang meningkatkan terkait pemanfaatan software untuk membuat video pembelajaran yang dilihat dari nilai pretest dan postest. Sedangkan kemampuan dalam pembuatan media ditunjukkan dari produk media pembelajaran yang telah dibuat oleh guru.

\section{UCAPAN TERIMA KASIH}

Ucapan terima kasih kami sampaikan kepada DRPM Ristek BRIN yang telah mendanai kegiatan PPUPIK Cendekia.

\section{DAFTAR PUSTAKA}

Barra, E., Aguirre Herrera, S., Pastor Caño, J. Y., \& Quemada Vives, J. (2014). Using Multimedia and Peer Assessment To Promote Collaborative E-Learning. New Review of Hypermedia and Multimedia, 20(2), 103-121. https://doi.org/10.1080/13614568.2013.857728

Dai, W., \& Fan, L. (2012). Discussion about the Pros and Cons and Recommendations for Multimedia Teaching in Local Vocational Schools. Physics Procedia, 33, 1144-1148. https://doi.org/10.1016/j.phpro.2012.05.188.

Hanum, N. S. (2013). Keefektifan E-Learning sebagai media pembelajarn (studi evaluasi model pembelajarn E-Learning SMK Telkom Sandhy Putra Purwokerto). Jurnal Pendidikan Vokasi, 3(1), 90-102. https://doi.org/10.21831/jpv.v3i1.1584 
Hendriyani, Y., Delianti, V. I., \& Mursyida, L. (2018). Analisis Kebutuhan Pengembangan Media Pembelajaran Berbasis Video Tutorial. JTIP: Jurnal Teknologi Informasi dan Pendidikan, 11(2), 85-88.

Herbst, P., \& Chazan, D. (2015). Studying Professional Knowledge Use in Practice Using Multimedia Scenarios Delivered Online. International Journal of Research and Method in Education, 38(3), 272-287. https://doi.org/10.1080/1743727X.2015.1025742.

Kumar, J. A., Muniandy, B., \& Wan Yahaya, W. A. J. (2019). Exploring The Effects Of Emotional Design and Emotional Intelligence in Multimedia-Based Learning: an Engineering Educational Perspective. New Review of Hypermedia and Multimedia, 25(1-2), 1-3-. https://doi.org/10.1080/13614568.2019.1596169

Kusuma, Jaka Wijaya; Jefri, Ulfi; Surnani, Endang; Pratiwi, Ika; Kurniawan, E. (2020). PELATIHAN PENGGUNAAN APLIKASI CLASSDOJO SEBAGAI UPAYA PENINGKATAN PEMBELAJARAN JARAK JAUH BAGI GURU SD IT BINA BANGSA DI ERA KENORMALAN BARU. JPKM-Aphelion (Jurnal Pengabdian Kepada MasyarakatAphelion), 1(01), 57-67. http://openjournal.unpam.ac.id/index.php/JPKA/article/view/6906

Marjuni, A., \& Harun, H. (2019). Penggunaan Multimedia Online Dalam Pembelajaran. Jurnal Idaarah, III(2), 194-204.

Marlena, N., Dwijayanti, R., \& Edwar, M. (2018). Pengembangan Media Pembelajaran Multimedia Interaktif Berbasis Flash untuk Meningkatkan Hasil Belajar Mahasiswa. Jurnal Pendidikan Ekonomi Dan Bisnis (JPEB), 6(1), 45-51. https://doi.org/doi.org/10.21009/JPEB.006.1.5

Nopriyanti, N., \& Sudira, P. (2015). Pengembangan Multimedia Pembelajaran Interaktif Kompetensi Dasar Pemasangan Sistem Penerangan dan Wiring Kelistrikan di SMK. Jurnal Pendidikan Vokasi, 5(2), 222-235. https://doi.org/10.21831/jpv.v5i2.6416.

Rusmiyati, I., Nurkamto, J., \& Haryanto, S. (2014). Penggunaan Multimedia Dalam Pembelajaran Bahasa Sastra Indonesia di SMPN 2 Bawen Kabupaten Semarang. Jurnal Teknologi Pendidikan Dan Pembelajaran, 2(2), 171-184. http://jurnal.fkip.uns.ac.id.

Yang, X.-P., Liu, X.-X., Guo, Y.-H., \& Wang, S.-J. (2012). Optimization and Application of Multimedia Teaching Means of Specialized Courses in Engineering. Energy Procedia, 17, 1878-1884. https://doi.org/10.1016/j.egypro.2012.02.326. 